\title{
Analisis Penalaran Matematis Pada Operasi Baris Elementer Untuk Menyelesaikan Persamaan Linier
}

\author{
Pandhu Eko Santoso ${ }^{1)}$, Tri Yuni Hendrowati ${ }^{2}$, Rahman Cahyadi ${ }^{3)}$ \\ 1),2),3) Universitas Muhammadiyah Pringsewu \\ email: $\underline{\text { rahmancahyadi@umpri.ac.id }}$
}

\begin{abstract}
Abstrak
Penelitian ini bertujuan untuk 1) mengetahui kemampuan penalaran matematis operasi baris elementer untuk menyelesaikan persamaan 2) penelitian ini adalah jenis penelitian deskriptif 3) hasil penelitian ini adalah rata-rata siswa masih belum dapat membuktikan dasar operasi baris dengan benar. Terlihat bahwa 100\% siswa yang mencapai indikator mengajukan kecurigaan, 38\% indikator jangkauan manipulasi matematika, 38\% indikator jangkauan menemukan pola atau ciri-ciri gejala matematika untuk digeneralisasi, 38\% indikator jangkauan menyusun bukti yang memberikan alasan atau bukti kebenaran. solusi, 38\% mencapai indikator menarik kesimpulan dari pernyataan, dan 38\% mencapai indikator memeriksa validitas argumen.
\end{abstract}

Kata kunci: Penalaran Matematis, Penalaran, Manipulasi Matematika

\section{PENDAHULUAN}

Hasil analisis pekerjaan mahasiswa pra penelitian diperoleh masih banyak mahasiwa yang belum mampu melakukan kemampuan penalaran matematis diantaranya kemampuan mengajukan dugaan, melakukan manipulasi matematika, menemukan pola atau sifat dari gejala matematis untuk membuat generalisasi, menyusun bukti memberikan alasan atau bukti terhadap kebenaran solusi, menarik kesimpulan dari pernyataan, serta memeriksa kesahihan suatu argumen. Penelitian ini dilakukan pada matakuliah aljabar linier pada materi operasi baris elementer. Dari hasil wawancara dengan dosen pegampu mata kuiah aljabar linier, ditemukan banyak mahasiswa yang mengalami kesalahan pada saat melakukan operasi baris elementer sehingga hasil belajar yang di peroleh tidak maksimal. kemampuan penalaran matematis ini tentunya tidak terlepas dari dalam diri mahasiswa itu sendiri, bagaimana sikap siswa terhadap belajar, konsentrasi belajar dan kebiasaan belajar. Hal ini sejalan dengan penelitian sebelumnya yang sudah dilakukan oleh cahyadi (2018) yang menyatakan bahwa perilaku prokrastinasi akademik yang berasal dari dalam diri mahasiswa atau faktor 
internal prokrastinasi lebih dominan sebagai faktor prokrastinasi akademik yang mengakibatkan hasil belajarnya rendah. Penelitian ini bertujuan untuk mendeskripsikan kemampuan penalaran matematis mahasiswa pada operasi baris elementer. Kemampuan penalaran matematis yang dimaksud adalah kemampuan berpikir menurut alur kerangka berpikir tertentu berdasarkan konsep atau pemahaman yang telah didapat sebelumnya. Kemudian konsep atau pemahaman tersebut saling berhubungan satu sama lain dan diterapkan dalam permasalahan baru sehingga didapatkan keputusan baru yang logis dan dapat dipertanggungjawabkan atau dibuktikan kebenarannya. Penelitian T. Muharom (2014), judul dari penelitian ini adalah pengaruh pembelajaran dengan model kooperatif Tipe Student Teams Achievement Division (STAD) Terhadap Kemampuan Penalaran Dan Komunikasi Matematik Peserta Didik Di SMK Negeri Manonjaya Kabupaten Tasikmalaya. Hasil dari penelitian ini adalah untuk mengetahui kemampuan penalaran dan komunikasi matematik siswa SMK Negeri Manonjaya Kabupaten Tasikmalaya yang dikembangkan pada model kooperatif Tipe Student Teams Achievement Division (STAD).

\section{METODE PENELITIAN}

Populasi penelitian ini adalah mahasiswa pendidikan matematika angkatan 2015 sebanyak 21 mahasiswa. Penelitian ini dilakukan di Sekolah Tinggi Keguruan dan Ilmu Pendidikan Muhammadiyah Pringsewu Lampung (STKIP MPL). Penelitian ini merupakan penelitian deskriptif, dan untuk mendapatkan data dalam penelitian ini, peneliti menggunakan soal tes dan pedoman wawancara, serta teknik analisis data yang digunakan yaitu menyajikan data dan menarik kesimpulan. Proses analisis data dalam penelitian ini adalah mendeskripsikan hasil data. Hasil deskripsi ini dilakukan berdasarkan indikator yang dicapai mahasiswa dalam menyelesaikan soal, sehingga dapat diketahui pencapaian indikator penalaran matematis. Selain mendeskripsikan hasil dari tes, peneliti juga mendeskripsikan hasil yang diperoleh dari wawancara. Selanjutnya untuk memudahkan dalam mengetahui pencapaian kemampuan penalaran matematis mahasiswa, maka proses selanjutnya adalah membuat persentase pencapaian kemampuan penalaran matematis mahasiswa.

\section{HASIL DAN PEMBAHASAN}

Berdasarkan hasil tes tulis dan wawancara selanjutnya peneliti membuat keputusan terkait dengan tes kemampuan penalaran matematis mahasiswa pada Program Studi Pendidikan Matematika STKIP MPL tahun akademik 2015/2016 yang telah mengikuti mata kuliah Aljabar Linier untuk menentukan sejauh mana indikator-indikator kemampuan penalaran matematis yang mampu dicapai mahasiswa sesuai dengan Analisis Kemampuan hasil jawaban yang peneliti tentukan. Analisis Kemampuan tersebut dapat dilihat pada 
Tabel 1 tentang analisis kemampuan pencapaian indikator Kemampuan Penalaran Matematis Mahasiswa berikut:

Tabel 1. Analisis Kemampuan Pencapaian Indikator

\begin{tabular}{|c|c|c|c|c|c|c|c|c|c|c|c|c|c|}
\hline \multirow{3}{*}{ No } & \multirow{3}{*}{ INISIAL } & \multicolumn{12}{|c|}{ Soal - Indikator } \\
\hline & & \multicolumn{6}{|c|}{1} & \multicolumn{6}{|c|}{2} \\
\hline & & 1 & 2 & 3 & 4 & 5 & 6 & 1 & 2 & 3 & 4 & 5 & 6 \\
\hline 1 & LA & $\sqrt{ }$ & $x$ & $x$ & $x$ & $x$ & $x$ & $\sqrt{ }$ & $x$ & $x$ & $x$ & $x$ & $x$ \\
\hline 2 & DR & $\sqrt{ }$ & $x$ & $x$ & $x$ & $x$ & $x$ & $\sqrt{ }$ & $x$ & $x$ & $x$ & $x$ & $x$ \\
\hline 3 & DB & $\sqrt{ }$ & $x$ & $x$ & $x$ & $x$ & $x$ & $\sqrt{ }$ & $x$ & $x$ & $x$ & $x$ & $\times$ \\
\hline 4 & $A G$ & $\sqrt{ }$ & $x$ & $x$ & $x$ & $x$ & $x$ & $\sqrt{ }$ & $\sqrt{ }$ & $\sqrt{ }$ & $\sqrt{ }$ & $\sqrt{ }$ & $\sqrt{ }$ \\
\hline 5 & MY & $\sqrt{ }$ & $x$ & $x$ & $x$ & $x$ & $x$ & $\sqrt{ }$ & $\sqrt{ }$ & $\sqrt{ }$ & $\sqrt{ }$ & $\sqrt{ }$ & $\sqrt{ }$ \\
\hline 6 & $B D$ & $\sqrt{ }$ & $x$ & $x$ & $x$ & $x$ & $\times$ & $\sqrt{ }$ & $x$ & $x$ & $x$ & $x$ & $x$ \\
\hline 7 & LU & $\sqrt{ }$ & $x$ & $x$ & $x$ & $x$ & $x$ & $\sqrt{ }$ & $x$ & $x$ & $x$ & $x$ & $x$ \\
\hline 8 & LH & $\sqrt{ }$ & $x$ & $x$ & $x$ & $x$ & $\times$ & $\sqrt{ }$ & $x$ & $x$ & $x$ & $x$ & $\times$ \\
\hline 9 & AS & $\sqrt{ }$ & $x$ & $x$ & $x$ & $x$ & $x$ & $\sqrt{ }$ & $\sqrt{ }$ & $\sqrt{ }$ & $\sqrt{ }$ & $\sqrt{ }$ & $\sqrt{ }$ \\
\hline 10 & LAS & $\sqrt{ }$ & $\times$ & $x$ & $x$ & $x$ & $\times$ & $\sqrt{ }$ & $x$ & $x$ & $x$ & $x$ & $x$ \\
\hline 11 & DN & $\sqrt{ }$ & $\times$ & $x$ & $x$ & $x$ & $\times$ & $\sqrt{ }$ & $x$ & $x$ & $x$ & $x$ & $x$ \\
\hline 12 & $A R$ & $\sqrt{ }$ & $x$ & $x$ & $x$ & $x$ & $x$ & $\sqrt{ }$ & $\sqrt{ }$ & $\sqrt{ }$ & $\sqrt{ }$ & $\sqrt{ }$ & $\sqrt{ }$ \\
\hline 13 & NC & $\sqrt{ }$ & $x$ & $x$ & $x$ & $x$ & $x$ & $\sqrt{ }$ & $\sqrt{ }$ & $\sqrt{ }$ & $\sqrt{ }$ & $\sqrt{ }$ & $\sqrt{ }$ \\
\hline 14 & DA & $\sqrt{ }$ & $x$ & $x$ & $x$ & $x$ & $x$ & $\sqrt{ }$ & $x$ & $x$ & $x$ & $x$ & $x$ \\
\hline 15 & GK & $\sqrt{ }$ & $x$ & $x$ & $x$ & $x$ & $x$ & $\sqrt{ }$ & $\sqrt{ }$ & $\sqrt{ }$ & $\sqrt{ }$ & $\sqrt{ }$ & $\sqrt{ }$ \\
\hline 16 & SN & $\sqrt{ }$ & $x$ & $x$ & $x$ & $x$ & $\times$ & $\sqrt{ }$ & $x$ & $x$ & $x$ & $x$ & $x$ \\
\hline 17 & VR & $\sqrt{ }$ & $x$ & $x$ & $x$ & $x$ & $x$ & $\sqrt{ }$ & $x$ & $x$ & $x$ & $x$ & $x$ \\
\hline 18 & L & $\sqrt{ }$ & $x$ & $x$ & $x$ & $x$ & $x$ & $\sqrt{ }$ & $x$ & $x$ & $x$ & $x$ & $x$ \\
\hline 19 & NS & $\sqrt{ }$ & $x$ & $x$ & $x$ & $x$ & $x$ & $\sqrt{ }$ & $\sqrt{ }$ & $\sqrt{ }$ & $\sqrt{ }$ & $\sqrt{ }$ & $\sqrt{ }$ \\
\hline 20 & FN & $\sqrt{ }$ & $x$ & $x$ & $x$ & $x$ & $x$ & $\sqrt{ }$ & $x$ & $x$ & $x$ & $x$ & $x$ \\
\hline 21 & $\mathrm{FR}$ & $\sqrt{ }$ & $x$ & $x$ & $x$ & $x$ & $\times$ & $\sqrt{ }$ & $\sqrt{ }$ & $\sqrt{ }$ & $\sqrt{ }$ & $\sqrt{ }$ & $\sqrt{ }$ \\
\hline \multicolumn{2}{|c|}{ Jumlah } & 21 & 0 & 0 & 0 & 0 & 0 & 21 & 8 & 8 & 8 & 8 & 8 \\
\hline \multicolumn{2}{|c|}{ Presentase } & $\begin{array}{c}100 \\
\%\end{array}$ & $0 \%$ & $0 \%$ & $0 \%$ & $0 \%$ & $0 \%$ & $\begin{array}{c}100 \\
\%\end{array}$ & $38 \%$ & $38 \%$ & $38 \%$ & $38 \%$ & $38 \%$ \\
\hline
\end{tabular}

\section{Keterangan :}

1) Indikator mengajukan dugaan; 2) Indikator manipulasi matematis; 3)Indikator menyusun bukti, memberikan alasan atau bukti terhadap kebenaran solusi

4) Indikator menemukan pola atau sifat dari gejala matematis dan membuat generalisasi; 5)Indikator menarik kesimpulan dari pernyataan; 6)Indikator memeriksa kesahihan suatu argument; $\sqrt{ }:$ Mencapai indikator $; \times:$ Tidak mencapai indikator

Hasil penelitian menunjukkan bahwa sebagian besar mahasiswa masih belum mampu membuktikan soal operasi basis elementer secara benar. Hal ini ditunjukkan 21 mahasiswa atau $100 \%$ yang mencapai indikator mengajukan dugaan, 8 mahasiswa atau $38 \%$ yang mencapai indikator 
melakukan manipulasi matematis, 8 mahasiswa atau 38\% yang mencapai indikator menemukan pola atau sifat dari gejala matematis untuk membuat generalisasi, 8 mahasiswaatau 38\% yang mencapai indikator menyusun bukti memberikan alasan atau bukti terhadap kebenaran solusi, 8 mahasiswa atau $38 \%$ yang mencapai indikator menarik kesimpulan dari pernyataan, dan 8 mahasiswa atau 38\% yang mencapai indicator memeriksa kesahihan suatu argumen, menurut Asmar Bani (2011:13) menyatakan bahwa materi matematika dan penalaran matematika merupakan dua hal yang tidak dapat dipisahkan. Materi matematika dipahami melalui penalaran, dan penalaran yang dipahami dan dilatihkan melalui belajar matematika.

Hasil penelitian data yang meliputi penyajian data dan verifikasi data diperoleh jenis-jenis kesalahan yang dilakukan oleh mahasiswa dalam menyelesaikan soal-soal pada konsep matriks dengan operasi baris elementer penyebabnya adalah sebagai berikut:

\section{Indikator kemampuan mengajukan dugaan.}

Pada indikator inilah subjek penelitian banyak melakukan kesalahan yaitu dengan tidak menuliskan ada yang diketahui oleh soal dan apa yang harus dikerjakan oleh subjek penelitian, tetapi bisa menjawab secara lisan. Kemampuan mengajukan dugaan mahasiswa sudah baik meskipun tidak bisa menuliskan pada kertas dengan baik, subjek dapat menjelaskan dengan lisan secara baik apa yang diketahui dan ditanyakan pada soal. Hal ini sesuai dengan Peraturan Dirjen Dikdasmen No.506/C/PP/2004 pada indikator kemampuan mengajukan dugaan yang menyatakan mahasiswa mempunyai kemampuan mengajukan dugaan jika mampu merumuskan kemungkinan pemecahan sesuai dengan pengetahuam yang dimilikinya.

\section{Indikator kemampuan melakukan manipulasi matematis}

Pada indikator ini sebagian subjek penelitian masih salah dalam mengerjakan operasi baris elementer, sehingga akan mempengaruhi hasil akhir nantinya. Berdasarkan hasil tes sebagian mahasiswa tidak mampu melakukan manipulasi matematis dan begitupun dengan hasil wawancara yang didapat sebagian subjek tidak mampu melakukan manipulasi matematis karena tidak tahu akan konsep dasarnya. Menurut peneliti subjek tidak tahu konsep dasar karena pada saat mengikuti perkuliahan subjek hanya mendengarkan dan mencatat, tetapi tidak mengembangkan daya ingat dan mengolah penalaran yang diperoleh dari dosen, menurut (Benson Adesina Adegoke, 2013) menyatakan diantaranya perlunya guru matematika untuk menyusun intervensi program yang akan membantu siswa mengembangkan dan meningkatkan kemampuan penalaran matematika mereka dan pada akhirnya meningkatkan pencapaian mereka dalam matematika. Hal ini 
berarti peran guru sangatlah penting dalam membantu siswa meningkatkan kemampuan penalaran serta meningkatkan daya pikir yang dimiliki siswa.

Indikator kemampuan menyusun bukti, memberikan alasan, atau bukti terhadap kebenaran solusi

Dari hasil tes dan wawancara sebagian subjek tidak mampu menyusun bukti karena subjek tidak dapat melakukan manipulasi matematis sehingga subjek tidak mampu menyusun bukti. Dari hal ini menurut peneliti, subjek tidak dapat melakukan kemampuan menyusun bukti, memberikan alasan, atau bukti terhadap kebenaran solusi karena tidak dapat menyelidiki soal dengan baik, dalam hal penyelidikan subjek harus dapat mampu mengetahui dugaan dari soal tersebut lalu melakukan langkah manipulasi matematisnya dengan benar sehingga subjek dapat menyusun bukti dengan benar pula. Hal ini sesuai dengan Peraturan Dirjen Dikdasmen No.506/C/PP/2004 pada indikator menyusun bukti, memberikan alasan, atau bukti terhadap kebenaran solusi, mahasiswa memiliki kemampuan ini jika dapat melakukan penyelidikan dengan benar.

\section{Indikator kemampuan menarik kesimpulan dari suatu pernyataan}

Dari hasil tes dan wawancara sebagian subjek penelitian belum mampu menarik kesimpulan dari suatu pernyataan karena dalam menyusun bukti, dan melakukan manipulasi masih melakukan kesalahan. Menurut peneliti sebagian subjek belum bisa menggunakan pengetahuannya dengan maksimal hal ini dikarenakan pada saat belajar di perkuliahan mahasiswa tidak mengasah pengetahuan yang dimiliki. Hal ini juga sesuai dengan Peraturan Dirjen Dikdasmen No.506/C/PP/2004 pada indikator kemampuan menarik kesimpulan dari suatu pernyataan, mahasiswa dikatakan mempunyai indikator ini jika mampu memberdayakan pengetahuannya sedemikian rupa untuk menghasilkan sebuah pemikiran.

\section{Indikator kemampuan memeriksa kesahihan suatu argumen}

Dari hasil tes dan wawancara sebagian subjek tidak memeriksa kembali kebenaran dari hasil pekerjaannya. Menurut peneliti sebagian mahasiswa tidak memeriksa kembali karena mahasiswa tidak bisa mengerjakan soalnya dengan baik. Hal ini juga sesuai dengan Peraturan Dirjen Dikdasmen No.506/C/PP/2004 pada indikator kemampuan memeriksa kesahihan suatu argumen, mahasiswa dikatakan mempunyai kemampuan memeriksa kesahihan suatu argumen jika mahasiswa memeriksa atau mengecek kembali hasil pekerjaannya.

Indikator kemampuan menemukan pola atau sifat dari gejala matematis untuk membuat generalisasi

Dari hasil tes dan wawancara sebagian subjek tidak memenuhi indikator kemampuan menemukan pola atau sifat dari gejala matematis untuk 
membuat generalisasi. Menurut peneliti kemampuan menemukan pola akan bisa dilakukan jika mahasiswa mampu melakukan kemampuan manipulasi matematis dan menyusun bukti. Hal ini juga sesuai dengan Peraturan Dirjen Dikdasmen No.506/C/PP/2004 pada indikator kemampuan menemukan pola atau sifat dari gejala matematis untuk membuat generalisasi dapat tercapai jika mahasiswa mampu menemukan pola lalu dikembangkan kedalam kalimat matematisnya.

Berdasarkan hasil analisis tes dan wawancara mahasiswa, kesalahan mahasiswa dalam melakukan pembuktian pada operasi baris elementer diakibatkan karena kesulitan dalam memahami soal yang diberikan. Hal ini menunjukkan bahwa faktor yang berasal dari dalam diri mahasiswa begitu dominan. Kurangnya pemahaman mahasiswa pada operasi baris elementer diakibatkan karena mahasiswa hanya mencatat ulang soal dan latihan yang ditulis oleh dosen di papan tulis dan tidak mencari sumber lain sebagai bahan untuk menambah pemahamannya, sehingga dapat dikatakan bahwa faktor internal begitu mempengaruhi mahasiswa dalam mempelajari operasi baris elementer. Selain kurangnya pemahaman, masalah lain yaitu kurangnya minat dan motivasi belajar mahasiswa yaitu mahasiswa hanya belajar ketika akan diadakan kuis, ujian tengah semester, dan ujian akhir semester. Oleh karena itu mahasiswa harus mampu merubah dan menghilangkan kebiasaan tersebut, sehingga pemahaman mahasiswa menjadi lebih baik dan berakibat baik juga pada meningkatnya hasil belajar mahasiswa. menurut Asmar Bani (2011:13) menyatakan bahwa materi matematika dan penalaran matematika merupakan dua hal yang tidak dapat dipisahkan. Materi matematika dipahami melalui penalaran, dan penalaran yang dipahami dan dilatihkan melalui belajar matematika.

\section{SIMPULAN}

Hasil penelitian menunjukkan bahwa rata-rata mahasiswa masih belum mampu membuktikan konsep matriks secara benar. Hal ini ditunjukkan 21 mahasiswa atau $100 \%$ yang mencapai indicator mengajukan dugaan, 8 mahasiswa atau $38 \%$ yang mencapai indicator melakukan manipulasi matematis, 8 mahasiswa atau $38 \%$ yang mencapai indicator menemukan pola atau sifat dari gejala matematis untuk membuat generalisasi, 8 mahasiswa atau 38\% yang mencapai indicator menyusun bukti memberikan alas an atau bukti terhadap kebenaran solusi, 8 mahasiswaatau 38\% yang mencapai indikato rmenarik kesimpulan dari pernyataan, dan 8 mahasiswa atau $38 \%$ yang mencapai indikator memeriksa kesahihan suatu argumen. 


\section{DAFTAR PUSTAKA}

Bani, A. (2011). "Meningkatkan Kemampuan Pemahaman dan Penalaran Matematika Sekolah Menengah Pertama Melalui Pembelajaran Penemuan Terbimbing”. Edisi Khusus (1). 12-20.

Cahyadi, R (2018). "Prokrastinasi akademik Mahasiswa Pada Mata kuliah Aljabar Linier". Jurnal e-dumath. Vol.4 46-57 https://ejournal.umpri.ac.id/index.php/edumath/article/view/587

Depdiknas. 2004. Peraturan tentang Penilaian Perkembangan Anak Didik SMP No.506/C/Kep/PP/2004 Tanggal 11 November 2004. Jakarta: Ditjen Dikdasmen Depdiknas

Muharom, T. (2014). "Pengaruh Pembelajaran Dengan Model Kooperatif Tipe Teams Games Tournament Terhadap Kemampuan Penalaran dan Komunikasi Matematik Peserta Didik di SMK Negeri Manonjaya Kabupaten Tasikmalaya". Jurnal Pendidikan dan Keguruan 1(1). 1-11. 